International Journal of Business Management and Economic Review

Vol. 4, No. 06; 2021

ISSN: 2581-4664

\title{
AN ASSESSMENT OF THE IMPLICATIONS OF THE MARKET FOCUS OF THE AGRICULTURAL PROMOTION POLICY ON FOOD SECURITY IN NIGERIA, 2016- 2021
}

\author{
Okorie Albert, Ph.D \\ Department of Political Science, University of Nigeria, Nsukka \\ Louiemarie Adaeze Ifem \\ Department of Political Science, University of Nigeria, Nsukka \\ Hillary Obike \\ Department of Political Science, Abia State University
}

http://doi.org/10.35409/IJBMER.2021.3337

\begin{abstract}
Agriculture is a critical sector of every state's economy with high potentials for employment generation, food security and poverty alleviation. Nigeria's landmass is about 923,763 square kilometer, out of which 37.33 percent is arable and has favourable weather for farming. This presents a clear potential for self-sufficiency in food production and export. However, in reality, Nigeria faces huge food security challenges that exacerbate hunger and poverty. This study investigated the implications of the market focus of the Agricultural Promotion Policy (APP) on food security in Nigeria. The study which was anchored on the Rentier State Theory argues that the Nigerian State is not food secured because government's continuous dependence on oil is highly disincentive to the agricultural sector. Documentary method of data collection and the qualitative descriptive method of data analysis were employed for the investigation. The study reveals that market focus of the APP hindered food accessibility in Nigeria. Furthermore that the APP was basically keen at ensuring Nigeria's place in the export market rather than making domestic consumption a priority; hence led to poor availability of locally produced foods. In addition the policy which focused on value chain rather than production accounted for the increase in prices of food commodities. Hence the study recommends among others a demonstrable political will for diversification, incentivization of agricultural technology and evolution of robust micro-credit framework for farmers.
\end{abstract}

Keyword: Agriculture, Food Security, Agricultural Promotion Policy, Market Focus, Rentier State Theory.

\section{INTRODUCTION}

Nigeria's landmass is about 923,763 square kilometers, out of which 37.33 percent is arable and has favourable weather for farming. This presents a clear potential for self-sufficiency in food production and export (National Security Strategy, 2019). This positive climatic and arable environment in Nigeria is surely huge assets and enabler for tremendous agricultural growth for enhanced contribution to national development. However, in reality, Nigeria faces huge food security challenges that exacerbate hunger. Not less than $70 \%$ of the Nigerian population is surviving on less than a dollar per day, suffering hunger and poverty (Akerele, et al., 2016). Nigeria's food security challenges grow with its teeming population. At current food production 


\section{International Journal of Business Management and Economic Review}

Vol. 4, No. 06; 2021

ISSN: 2581-4664

growth rates, Nigeria remains unable to feed its population. With the discovery of crude oil in Nigeria, agriculture has gradually been neglected. Hence, Soludo (2004, p.678) commented on this when he stated that:

Despite the dominant role of the petroleum sector as the major foreign exchange earner, agriculture remains the mainstay of Nigeria's economy. In addition, to contributing the largest share of GDP, it is the largest nonoil export earner, the largest employer of labour, and a key contributor to wealth creation and poverty alleviation, as a large percentage of the population derives its income from agriculture and related activities. Over the years the rate of growth in agricultural production has stagnated and failed to keep pace with needs of a rapidly growing population, resulting in a progressive increase in import bills for food and industrial raw materials.

Several governments in Nigeria have made different policies for the development of Nigeria's agricultural sector. Some of these programmes and policies failed while some came up with a new name as a new administration came into power. These policies are as follows; the National Accelerated Food Production Project (NAFPP), the Nigerian Agricultural and Co-Operative Bank (NACB), the River Basin Development Authorities (RBDAs), Operation Feed the Nation (OFN), Agricultural Credit Guarantee Scheme (ACGS), Green Revolution Programmes (GRP), Agricultural Development Project (ADPs). Others include the First National Fadama Development Project (1991), National Special Programmes for Food Security (2003), National Fadama Development Project (2004), IFAD/NDDC/Community-Based Natural Resource Management Programmes (2001) and Agricultural Transformation Agenda (ATA) (2011) (Nwaobiala, 2015).

However, there has not been much positive result that has emerged from the implementation of these aforementioned programmes. According to Iwuchukwu and Igbokwe (2012), changes in Nigerian agricultural policies and programmes vary only in nomenclature and organizational framework, the new policies and programmes emphasize almost the same objectives like provision of food for the nation and exportation of the anticipated excess food to other countries.

Policy inconsistency or somersault has become a defining practice of successive administrations in Nigeria. Prior to the introduction of the APP for instance, there was the ATA which sought, amongst other things, to reintroduce the Nigerian economy to sustainable agriculture centered on business-like attitude driven by the private sector. That strategy was in place from 2011-2015. However, the ATA was not without its own challenges. It was on these challenges that the APP sought to remedy and build upon. According to Ibeawuchi (2018), the objectives of the APP can be summarized as follows;

- Integrate agricultural commodity value chains into the broader supply chain of the Nigerian and global industry, driving job growth, increasing the contribution of agriculture to wealth creation, and enhancing the capacity of the country to earn foreign exchange from agricultural exports, boosting agriculture's Share of Non-Oil Exports Earnings to $75 \%$.

- Promote the responsible use of land, water and other natural resources to create a vibrant agricultural sector offering employment and livelihood for a growing 


\section{International Journal of Business Management and Economic Review}

Vol. 4, No. 06; 2021

ISSN: 2581-4664

population. Facilitate the government's capacity to meet its obligations to Nigerians on food security, food safety and quality nutrition with agriculture's Share of Federal Budget at approximately $2.0 \%$.

The APP will elapse by the year 2021 and so far, the Nigerian government is yet to wrap her hands around the issue of food security in terms of affordability, accessibility and availability. As noted by the Global Food Security Strategy (2018), food availability, accessibility, and utilization remain significant challenges in Nigeria. Nigeria is the world's largest producer of cassava, yam, and cowpea, yet, due to low crop productivity, the country is a food deficit nation and depends on grain, livestock products, and fish imports to meet local demand (GFSS, 2018).

Scholars like Ojong and Anam (2018), noted that the APP as a strategy focuses on raising overall productivity and quality standards of food production in Nigeria. However, Odunze (2018) stated that the APP is a refreshed strategy established to put Nigeria in a direction aimed at increasing food production and income. Abdulrahaman (2013), is of the opinion that, the amount of statutory allocation given to the sector is too small for the sector to achieve its primary objective. Eze, Ikenna, Ugwu and Chima (2010), noted that access to credit is a problem for all farmers and is particularly acute for poor farmers. Most of the farmers in rural areas have little or no access to credit and loans without which it is unlikely that they will invest heavily in productivity. The beneficiaries of these agricultural policies are mainly people who are outside agricultural occupation. The government's insensitivity to the needs of the rural areas and lack of infrastructural development and incentives, through loans for farmers, invariably results in ruralurban migration (Albert and Isife, 2009).

The ability to have access to food depends on two major conditions: - economic access and physical access. Economic access depends on one's income, the price of food and the purchasing power of the people. Physical access depends on the availability and quality of infrastructure needed for the production and distribution of food (Metu, Okeyika and Maduka, 2016). Experts have argued that significant food and nutrition problems exist in Nigeria (Ahungwa et al, 2013). Recent estimates put the number of hungry people in Nigeria at over 53 million of the country's total population and that 52 per cent of the populace lives below the poverty line (Azubike, 2012). These scholars examined the implementation of APP but were not able to establish the nexus between the market focus of the policy, inadequate funding of programmes pursuant to the implementation of the Agricultural Promotion Policy, the neo liberal under pinning of the APP and food security in Nigeria.

\section{THEORETICAL FRAMEWORK}

This study adopts the rentier state theory. This theory was first postulated by Hossein Mahdavy in 1970. The theory of the rentier state is a complex of associated ideas concerning the patterns of development and the nature of states in economies dominated by external rent, particularly oil rent (Yates,1996). The idea of the rentier state assumed new importance in the decades following Mahdavy's work. His ideas experienced a kind of renaissance in the 1980s in the literature of scholars like Beblawi and Luciani (1987) who were interested in the impact of oil windfall on the nature of Arab States. Accordingly, Beblawi (1990, p.87), aptly captures the rentier mentality as:

A psychological condition with profound consequences for productivity where contracts are given as an expression of gratitude rather than as a reflection 


\section{International Journal of Business Management and Economic Review}

Vol. 4, No. 06; 2021

ISSN: 2581-4664

of economic rationale, civil servants see their principal duty as being available in their offices during work hours, businessmen abandon industry...the best and brightest abandon business and seek out lucrative government employment; manual labour and other work considered demeaning by the rentier is farmed out to foreign workers whose remittance flood out of the rentier economy.

According to this theory, four characteristics must be present in order for a state to be classified as rentier. First, the rentier economy of which the state is a subset must be one where rent situations predominate. Second, the origin of the rent must be external to the economy. In other words, the rent must come from foreign sources. Domestic rent, even if it were substantial enough to predominate is not sufficient to characterize such economy as rentier. Third, in a rentier state, only the few are engaged in the generations of rents, while majority are involved in the distribution and consumption. Therefore, an open economy with high levels of foreign trade is not rentier, even if it depends predominantly on rent (e.g. agriculture), because majority of the society is actively involved in the creation of wealth. Finally, the government must be the principal recipient of the external rent in the economy.

Consequent from the above, the external rents liberate the state from the need to extract income from the domestic economy. Thus, unlike a 'production state' that relies on taxation of the domestic economy for its income, Nigeria does not depend on domestic sources of revenue but rather is the primary source of revenue itself in the domestic economy. The theory of the rentier state postulates that there is a lackluster attitude prevalent among rentier states to their conditions of socio-economic and technological backwardness (Yates, 1996). This arise from the ability of the rentier state to use their huge foreign earnings to purchase 'welfare and prosperity' from outside. Thus, in Nigeria, instead of attending to the task of expediting the basic socio-economic transformations, the rentier elites' ability to embark on massive spending and consumption preempts some of the urgency for change and rapid growth. Hence, Nigeria's government response to the issue of food insecurity is one that favours massive importation of food.

The economic behavior of a rentier is distinguished from conventional economic behavior in that it embodies a break in the work-reward causation (Beblawi and Lucian, 1987). As noted by Yates (1996), rewards of income and wealth for the rentier do not come as the result of work, but rather are the result of chance or situation. That is, income and wealth are seen as situational or accidental rather than as the end result of a long process of systematic and organized production. Under this situation, there is a high tendency for people to seek employment only in businesses associated with the booming oil sector; hence, people seek out lucrative government employment since it is government that controls most of the oil wealth of the state which has little or no linkage with other sectors. This has a serious implication on the effort of achieving food security in Nigeria since the agrarian sector which has a strong rural base is undermined by massive rural-urban migration as more able-bodied people migrate to areas where they can have access to "white collar jobs associated with the booming oil sector. One consequence of the large amount of external rent available in a rentier economy is that the state tends to relax constraint on foreign exchange. Thus, the availability of foreign currency in such relative abundance means that the rentier state can acquire foreign goods without the usurious costs of exchange (Yates, 1996). This also implies that imported goods have the tendency to replace domestically produced goods, particularly in 


\section{International Journal of Business Management and Economic Review}

Vol. 4, No. 06; 2021

ISSN: 2581-4664

agriculture and manufacturing, which often cannot compete with foreign goods produced under economies of scale. The state purchases foodstuffs, which then compete with domestically produced foodstuffs in the local markets. This affects domestic agricultural production and domestic industries may become net consumers rather than net producers of the national income. It is in this light we explained the link between the failure of APP and food security in Nigeria. The core argument of rentierism is that when governments gain most of their revenues from external sources, such as resource rents or foreign assistance, they are freed from the need to levy domestic taxes and as a result become less accountable to the societies they govern (Collier 2003). That as the state becomes deeply involved in the economy the ruling elite can spend the rents for their own privileges, for reinforcing their own position of power and access to the rents, and for shortsighted public expenditure. As a result, state institutions are weakened and the rents are not utilized to guarantee long-term, sustainable socio-economic development including in huge investment on Agriculture (Beck, 2007).

This theory is relevant in explaining agricultural policy implementation issues and food security. This is because as demonstrated by relevant literatures, the problem bedeviling Nigeria is structural. The structure of the Nigerian economy is highly disincentive to the agricultural sector given that huge priority is given to the oil sector because of the rent it accrues to the ruling elite. Therefore a theory that can help explain the structural underpinning of the Nigerian economy and its consequences for policy implementation becomes more than fecund. Since the problem is structural, this theory has clearly explained the structural underpinning of the Nigerian economy and more importantly raised the policy implications for such. One of the policy implications is the tendency for the ruling elite to overlook other productive sectors of the economy like agriculture etc.

Furthermore, two critical measures can show that a state is still far from prioritizing a sector are as follows; either the state is not listening or paying attention to the problem by way of evident political will to match all that the policy has presented or that the state is not channeling enough resources to that sector in order for the problem to be addressed in tandem with all that have been envisaged in the policy. Hence, the agricultural sector of Nigeria is yet to receive adequate prioritization from the government because the political will and enough resources are still channeled towards oil. However, until the aforementioned priority given to oil is given to Agriculture, this policy and other subsequent agricultural policies are bound to fail.

\section{METHODOLOGY}

Documentary and observation methods were deployed in gathering data for the study. These methods help the researchers to glean information and data from already documented sources and ongoing activities in the agricultural sector in Nigeria. The justification for these methods is that they are very appropriate for contextual analysis and useful when the task is to glean, illuminate, interpret and extract valuable information in order to draw inference from the available evidence. Above all these methods were considered most appropriate given that secondary data constitute the bulk of the data used in the analysis. Besides, opinions of experts and critical stakeholders in the sector as expressed in the leading print and electronic media were equally elicited to validate and support data generated from documentary and observation methods. Therefore, we essentially relied on articles in journals and Nigerian newspapers, official publications of the Federal Ministry 


\section{International Journal of Business Management and Economic Review}

Vol. 4, No. 06; 2021

ISSN: 2581-4664

of Agriculture and Rural Development, Federal Ministry of Finance, Budget and National Planning, Regional and Sub-Regional Organizations such as African Union, Food and Agricultural Organization among others on the subject matter. The merits of secondary sources of data is that of economy and the fact that gathering of information does not require the co-operation of the concerned subjects of research (in this case stakeholders in Nigerian Government and other stakeholders in agricultural sector) about whom information are being sought.

Content analysis based on logical deduction was applied in the analysis of data generated in the study. It is the technique for making inference by objectively and systematically identifying specified characteristics of message (Stone 1966). The application of this technique involves examination of documents in order to generate information or inference based on the canons of scientific research. The justification of this method is that it enables the political inquirer to scrutinize the content of a document in order to understand its underlying structure, ideas and concepts and to quantify the message it relates (White 1983). Besides, content analysis can be used to delineate the characteristics of the communication itself, the causes or circumstances of the communication, and the effects of the communication on the audience. Moreover, content analysis is descriptive, dialectical, interactive, and multi-dimensional and falls within the intersection of the quantitative and qualitative continuum, and hence is most appropriate for the analysis of documentary evidence.

\section{An Overview of the Market Focus of the 2016 Agricultural Promotion Policy}

The APP proposes to privatize the Abuja Exchange Board and liberalize the market in partnership with the Security Exchange Commission to stimulate the participation of the private sector in agricultural marketing and trade. The two major problems highlighted by the FMARD in the APP (2016), are the inability of the country to meet its domestic requirement for food and the failure to meet the quality requirement for success in international markets. Both problems are results of an inefficient system riddled with issues that limit the sector's productivity starting from the input sector down to the processing/manufacturing and marketing sector of the Nigerian agribusiness system. Market access issues will be dealt with in partnership with private sector actors. Finally, Nigeria has not exploited global markets for its key foods e.g. cassava for a variety of reasons including quality, market knowledge and financing issues. In order to do that, the entire value chain of stakeholders needs to be involved in preparing crops for export (FMARD in APP, 2016). However, the FMARD (2016, p.24), further pointed out major constraints faced by the market scene of Nigeria. They are as follows;

- Infrastructure (road, power, farmer data, etc.)

- Lack of quality market information to enable identification of market opportunities, coordination among market actors and transparency

- Inadequate linkage within multiple agricultural supply chains

- Lack of coordination of efforts to improve efficiency between concerned government agencies

- Marketing constraints due to poor infrastructure and transportation (roads, railways etc.)

- Limited awareness and understanding of key export markets e.g. US, UK and EU 


\section{International Journal of Business Management and Economic Review}

Vol. 4, No. 06; 2021

ISSN: 2581-4664

- Poor understanding of the lifecycle of contamination of crops from early stage soil preparation to post-harvest handling.

Accordingly, possible solutions to the above constraints were also enumerated by the policy framework. According to FMARD in APP (2016, p.25);

- Crowd in private investments into the sector to deepen private service provision required to enable markets function effective

- Enhancing access to market information (process, opportunities etc.) by facilitating the establishment of national agricultural information system that provides easy access to information on markets, regulations, price discovery etc.

- Establishment of inter-ministerial working group to address the challenges of agricultural business

- Quality assurance and disease control via traceability

- Policy around quality control and standardization on crops, livestock, fisheries including apiculture

- Policy to improve infrastructure to reach markets

- Create export market support teams to work with other key agencies in MITI to provide seminars, guidance and support to Nigerian exporters to win in select markets e.g. China, US, EU and UK.

The APP also recognizes that to improve marketing and trade, the problem of infrastructure must be taken care of. Poor infrastructure is an impediment to trade and marketing in many ways such as high transportation costs, poor marketing information, and knowledge. Facilitating access to information on market prices will enable quicker and informed decision making on which local and export markets to target by farmers and processors (Odunze, 2019). Market Focus of Agricultural Promotion Policy and Availability of Locally Produced Commodities

Several efforts have been put in place by the current administration led by President Mohammadu Buhari to ensure a stable place for Nigeria in the export market. For instance, a report from Nigerian Export-Import Bank (NEXIM) (2019) holds that the export development facility is being introduced by NEXIM arising from the CBN's investment in a 50million naira debenture issued by NEXIM to stimulate and increase deliberate funding, especially to small and medium enterprises towards facilitating regional industrialization for value added exports and broadening Nigeria's export basket and market destination. However, just as the policy document guiding the agricultural sector of this current administration is keen on export; there is also a misplaced priority in the area of domestic consumption. Nigeria is yet to produce enough food that can satisfy the citizenry. According to FAO (2017), it is estimated that Nigeria has lost USD 10 billion in annual export opportunity from groundnut, palm oil, cocoa and cotton alone due to continuous decline in the production of those commodities. Food production have not kept pace with population growth, resulting in rising food imports and declining levels of national food self-sufficiency. 


\section{International Journal of Business Management and Economic Review}

Vol. 4, No. 06; 2021

ISSN: 2581-4664

As shown by the data from NBS (2019), trade in agricultural goods by Nigeria in 2018 had a deficit of $\$ 548$ billion, with the country importing far more agricultural goods than it exported. Out of $\$ 1.15$ trillion in agricultural goods traded between Nigeria and other countries, imports accounted for 73.82 per cent, while exports accounted for 26.18 per cent. For the year 2018, data so far made available by the NBS in its quarterly foreign trade statistics, showed that imported agricultural goods accounted for $\$ 852.11$ billion, a 4 per cent decrease from $\$ 886.7$ billion in 2017. The 2017 figure was however an increase of 35.09 per cent when compared to $\$ 656.4$ billion in 2016 . On the other hand, Nigeria exported a total of $\$ 302.24$ billion worth of agricultural goods in 2018.

From figure 5.1, it is evident that in 2018, there was a trade deficit in trade in Nigeria. Agricultural goods exports in the first quarter of 2018 was $\$ 73.25$ billion, representing 1.56 per cent of total exports. However, agricultural goods import cost $\$ 184.49$ billion, and represented 7.33 per cent of total imports. In total, agricultural goods accounted for $\$ 257.74$ billion and 3.57 per cent of total trade in the first quarter of 2018.

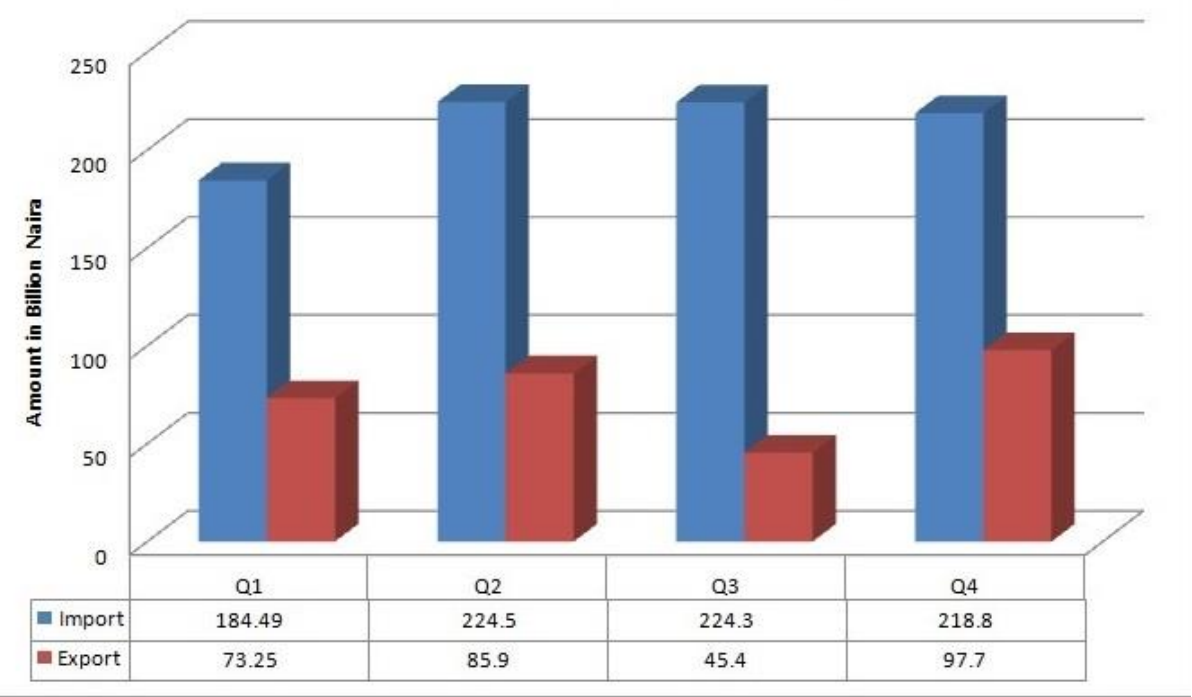

Figure One: Nigeria's Agricultural Trade in 2018 Source: NBS (2018).

According to the NBS (2019), Nigeria's agricultural export rose to N152.3 billion in the first six months of 2019. This is reflected in the foreign trade reports released by the covering the first and second quarter of 2019. According to the reports, Nigeria's major agricultural exports so far in 2019 include sesamum seeds (whether or not broken), cashew nuts, fermented cocoa beans, raw cocoa beans, other frozen shrimps and prawns, ginger and natural cocoa butter, ginger and agrofoods. However, analysis of reports gathered from the NBS showed that agricultural goods exported from Nigeria rose by $18 \%$ between the second half of 2018 and the first half of 2019 . Specifically, in the second half of 2018, agricultural export was estimated at $\$ 128.5$ billion, compared to $\$ 152.3$ billion in first 2019. Similarly, comparing Nigeria's agricultural export 


\section{International Journal of Business Management and Economic Review}

Vol. 4, No. 06; 2021

ISSN: 2581-4664

performance in the first half of 2019 with the corresponding half of 2018 (\$148.1 billion), it shows that agricultural export rose by $3 \%$ (Adesoji, 2019).

From figure one; sesamum seeds remain Nigeria's agricultural export biggest earner in the past years. The trend continued in the first half of 2019 as $\$ 60.6$ billion worth of sesamum seeds were exported from Nigeria. On the other hand, sesame oil and its fraction also made the top 10 agricultural export with $\$ 28.1$ million. The second most exported agricultural good from Nigeria is fermented cocoa beans. In the first half of 2019, Nigeria's cocoa beans export was estimated at \#31 billion. Other cocoa related products that made the top ten on the list include raw cocoa beans ( $\$ 17.15$ billion) and natural cocoa butter ( $\$ 2.26$ billion). Similarly, cashew nuts are Nigeria's third-biggest agricultural export. An estimated sum of $\$ 8$ billion was generated from cashew nut exported from Nigeria. Vietnam, India, Tanzania, Russia and Netherlands were Nigeria's biggest markets for cashew nuts in half-year 2019. Other goods on the list of Nigeria's major agricultural exports chain include ginger ( $\$ 2.26$ billion) and agro-food items ( $\$ 1.8$ billion) (NBS, 2019).

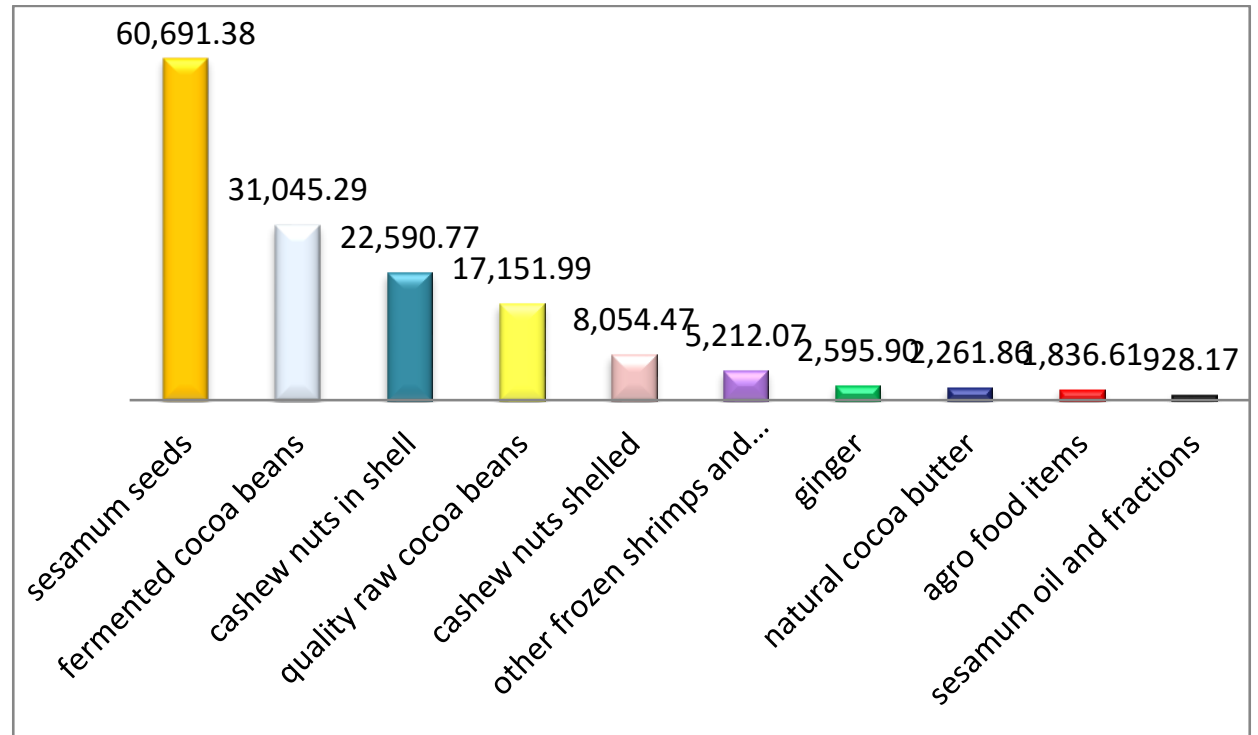

Figure Two: Nigeria Top Ten Agricultural Products in 2019

Source: NBS (2019).

Consequently, Adesoji (2019) reiterated that while top major agricultural exports rose significantly in half of 2019, this should not flatter the government as Nigeria still largely imports several agricultural products. A quick check into Nigeria's agriculture trade balance (import minus export) stood at a deficit of $\$ 176.4$ billion. Specifically, Nigeria imported $\$ 249.9$ billion agricultural products in second quarter of 2019, while export was just $\$ 7.4$ billion. This suggests that despite 


\section{International Journal of Business Management and Economic Review}

Vol. 4, No. 06; 2021

ISSN: 2581-4664

huge potentials in the sector, little has been achieved so far as Nigeria imports almost everything especially agricultural goods (Adesoji, 2019).

The availability of locally produced food in Nigeria is not proportionate to the teeming population of Nigeria which is currently over 200 million. Nigeria is among the food deficit states as observed by the statistical evidence from the Global Hunger index. Table one shows a tabular form of GHI's survey of Nigeria's hunger index. From table one, it is seen that Nigeria has always been backward in the global hunger index. The table indicates that Nigeria is being faced with the problem of hunger and this is as a result of food insecurity. This is so because the pattern of locally produced foods in Nigeria is poor. More so, if the local farmers cannot have access to agricultural technologies that will aid the production of locally produced food items, Nigeria's ranking on the GHI will not improve.

Table One: Surveys of Nigeria's Hunger Index, 2010-2019

\begin{tabular}{|l|l|l|}
\hline Year & $\begin{array}{l}\text { Nigeria } \\
\text { Global } \\
\text { Ranking }\end{array}$ & $\begin{array}{l}\text { Index } \\
\text { Score }\end{array}$ \\
\hline 2010 & 47 & 17.8 \\
\hline 2011 & 40 & 15.5 \\
\hline 2012 & 40 & 15.7 \\
\hline 2013 & 39 & 15.0 \\
\hline 2014 & 38 & 14.7 \\
\hline 2015 & 88 & 32.8 \\
\hline 2016 & 84 & 25.5 \\
\hline 2017 & 84 & 25.5 \\
\hline 2018 & 103 & 31.1 \\
\hline 2019 & 93 & 27.9 \\
\hline
\end{tabular}

Source: Authors' Compilation from GHI 2010-2019.

From figure three, available data show that Nigeria's index score by the GHI suggests that there has been a pattern of food unavailability in Nigeria. This has accounted for the level of hunger and malnutrition in the country. 


\section{International Journal of Business Management and Economic Review}

Vol. 4, No. 06; 2021

ISSN: 2581-4664

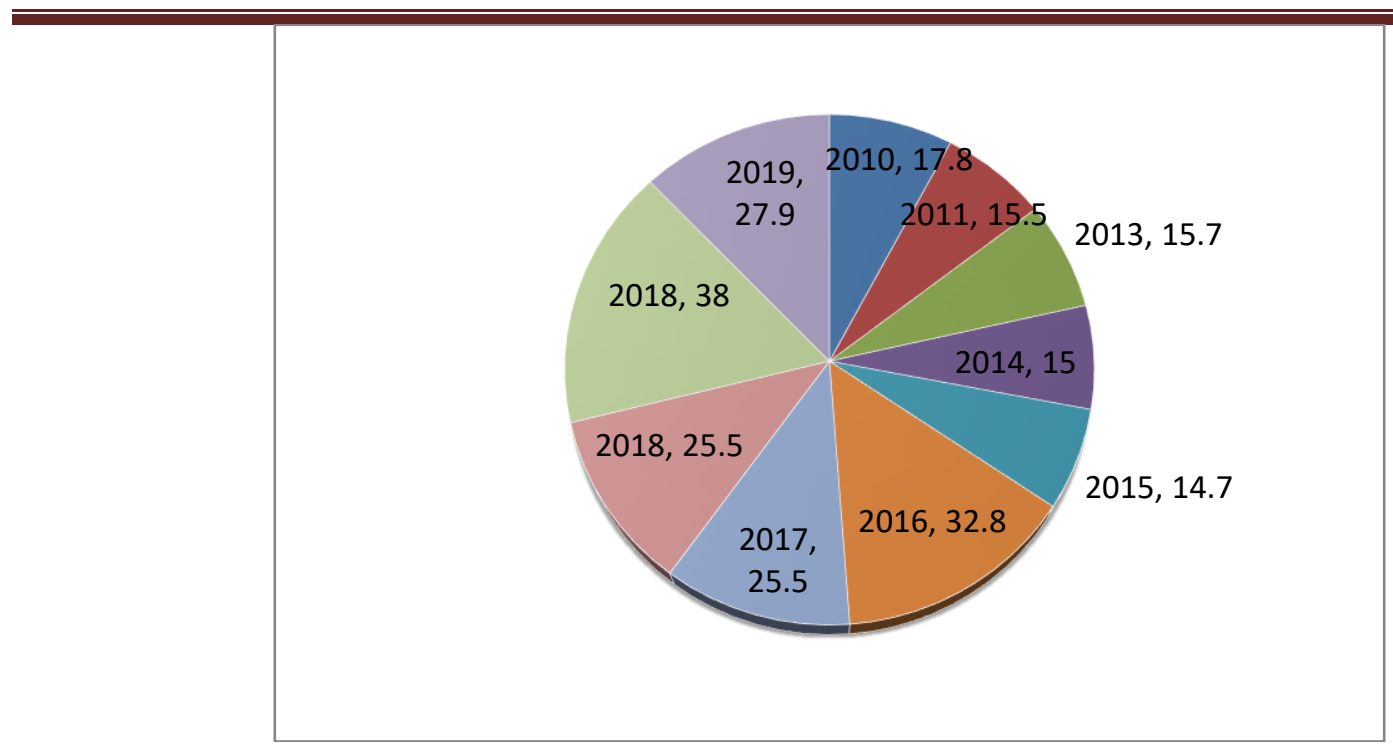

Figure Three: Nigeria's GHI Index Score

Source: Adapted by Authors from table one

According to FAO (2018), as the food system does not produce enough food to feed everyone, Nigeria depends on food imports to help meet the growing demand. Nigeria's food imports have more than quadrupled in the past decades, from a value of 964 million US dollars in 1995 to 4,566 million dollar in 2016. The most available staple foods providing energy in Nigeria are rice $(14.8 \%)$, cassava $(12.9 \%)$, maize $(10.6 \%)$ and yam $(10.1 \%)$. Major staples providing plant proteins are cowpea $(10.7 \%)$, groundnut $(8.1 \%)$ and soybean $(2.1 \%)$. The most available non-staple foods are meat products (14\%), non-leafy vegetables (13\%), leafy vegetables $(9.5 \%)$, and fats and oils (8.9\%) (Posthumus, et al 2019). According to Shem (2019), the value of locally produced wheat in Nigeria was estimated at $\$ 13$ million in 2016, rising to $\$ 15.5$ million in 2017 with projections that local producers would increase production to $\$ 16$ million and \$16.3 million in 2018 and 2019, respectively. But the national wheat production capacity is a drop in the ocean compared to the Nigerian market demand that was valued at $\$ 1.2$ billion in 2016 and $\$ 1.5$ billion in 2017, with estimates putting the 2018 and 2019 requirements at $\$ 1.65$ billion and $\$ 1.7$ billion, respectively (Shem 2019). Local wheat production in Nigeria has remained inadequate and other domestic supplies of substitute staples within Nigeria and neighboring countries have not kept pace with domestic demand (USDA, 2018). Food production indices have indicated that Nigeria produces about 100,000 metric tonnes of wheat while it consumes four million metric tonnes, with a deficit of 3.9 million tonnes yearly. Rice production shortfall for 2019 was 3.12 million tonnes while in 2020, it was 3.21 million tonnes. Hence, this deficit has been augmented through series of imports from different countries. According to USAD, (2018) the USA exported $\$ 300$ million and $\$ 400$ million worth of wheat to Nigeria in 2016 and 2017 respectively. Until the government of Nigeria does something about technological knowhow to enhance food production, local farmers will not be able to produce enough food in terms of quality and quantity for domestic consumption. Therefore, import substation can only be achieved in Nigeria when locally produced foods can 


\section{International Journal of Business Management and Economic Review}

Vol. 4, No. 06; 2021

ISSN: 2581-4664

sustain domestic demand. Subsistence farming is no longer a solution, Nigeria has to commercialize agricultural production and fully adopt mechanize farming. In addition, mechanization of the agricultural industry is the way out of solving Nigeria's problem. This can be achieved by matching up human input with mechanization, bringing in machinery and increase the scale of production, so that whatever the rural sector produces, it will match the population growth rate (Ojong, 2018).

\section{Agricultural Promotion Policy Focus on Value Chain and Rising Prices of Food Commodities}

According to FMARD (2016), the value chain approach of the APP focuses on the policy instruments of enterprise development across successive stages of the commodity for the development of crop, livestock and fisheries sub-sectors, production, storage, processing and utilization, marketing and consumption. Accordingly, the APP (2016), states that one of the policy thrust components of the present Government is prioritization of private sector as an engine to drive growth of Agricultural sector. This has required the development of some effective institutional frameworks to facilitate and coordinate the delivery of agribusiness and investment services. The post-harvest handling of agricultural produce is an important component of value chain development, and a catalyst for progressive and sustainable expansion of agribusiness, investment and agro-processing activities, thereby eradicating waste and ensuring import substitution, food security, wealth creation, employment generation, human capital development and security of human life and property. The APP (2016) noted the following as the major constraints affecting Nigeria's agricultural business and value chain;

- Lack of quality control and standard

- Low level of capacity of local fabricators

- Inaccessibility and high cost of fund for agro-processing

- Absence of low cost, market-oriented research prototyping

- Low private sector investment in agriculture/agro-processing

- Inadequate capacity for processing or crude processing methods

- Absence of rural infrastructure to support rural primary processing

- Absence of appropriate and adaptive processing technology at small scale level

- Poor quality of information and irregular dissemination impedes investors' abilities to properly plan investments

The above major constraints were also tackled with follow up plan by the policy thrust of APP. Hence, these constraints are set to be tackled by;

- Promotion of access to agro-processing through both public intervention and facilitation of private sector investment.

- Revitalization of Staple Crops Processing Zones, Agribusiness Incubation Centres and Agro-industrial parks

- Partnership with State Governments to incentivize agribusiness development including safeguards for small holders, rapid collateralization of land, and focused infrastructure access

- Provision of rural infrastructure, roads, water, electricity and others 
Vol. 4, No. 06; 2021

ISSN: 2581-4664

- Harmonization of standards, quality and other food safety measures for food security, market and trade

- Facilitation of provision of modern paddy handling equipment in key clusters

- Establishment of price discovery mechanisms and selective use of supports

- Establishment and leverage in a consultative capacity of a National Agribusiness Consultative and Advisory Forum (APP, 2016, p.26-27).

Despite this policy thrust, the agriculture sector is still largely underdeveloped primarily because the focus is largely on value chain rather than production. According to Mgbenka, (2016) Nigeria's agricultural value chain is characterized by $80 \%$ small holder farmers and a few commercial processors plagued by inadequate inputs, obsolete technology and poor financing.

Consequent from figure four the value chain of Nigeria's agriculture comprises of input supply, production, processing and marketing. These value chains are bedeviled with challenges as evident in figure four which includes poor accessibility to improved seedlings, frequent pest and disease attacks, high cost of power generation, illegal food imports etc. Lack of adequate infrastructures affects the production process of food in Nigeria. Nigeria is a big producer of many agricultural commodities. However, to achieve food sufficiency and deepen diversification, there should be need to increase production and value addition across key agriculture food products. 
International Journal of Business Management and Economic Review

Vol. 4, No. 06; 2021

ISSN: 2581-4664

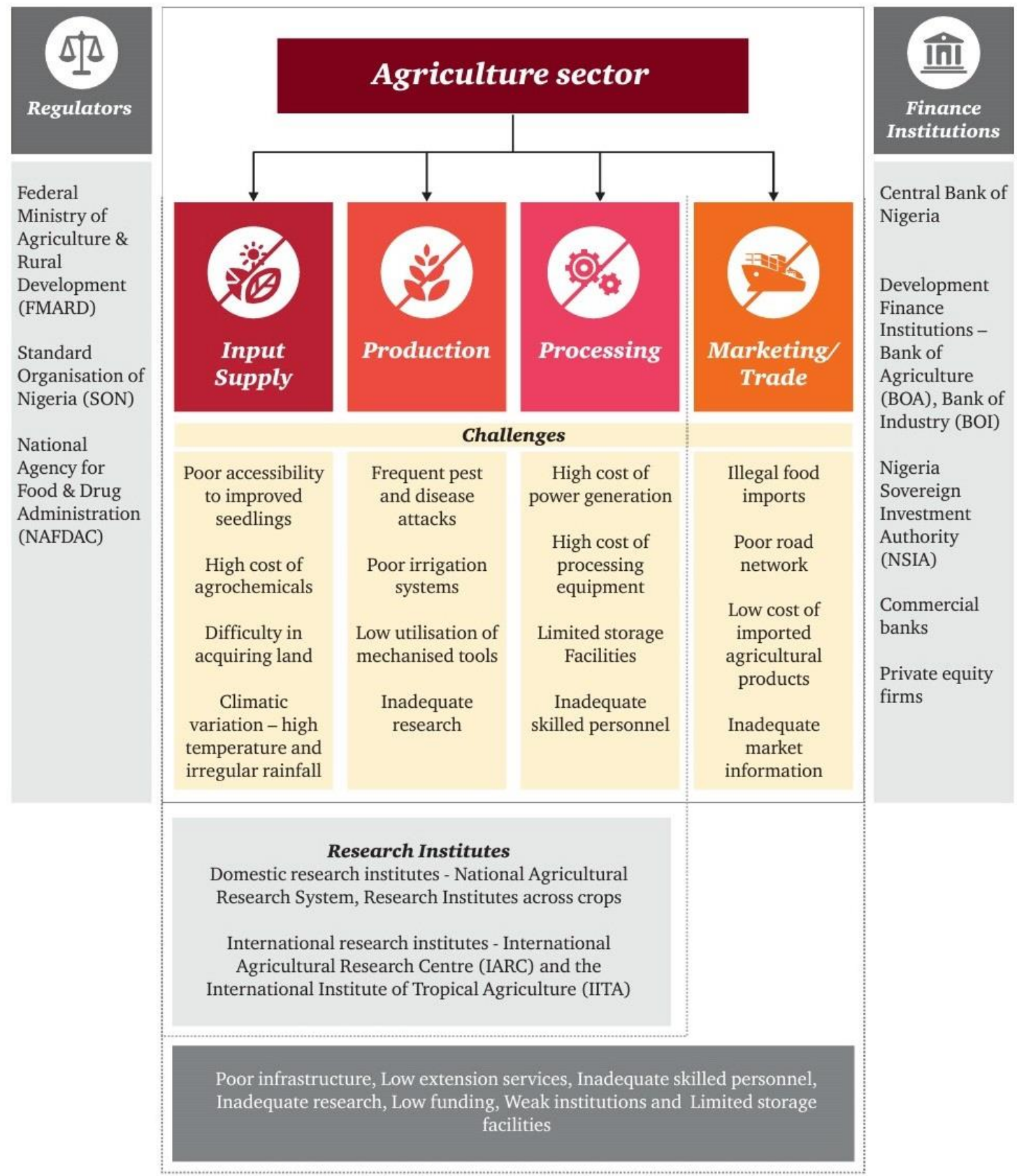

Figure Four: Nigeria’s Agricultural Value Chain

Source: PWC (2018).

The Nigerian population is presently growing at a thunderous $3 \%$ per annum. This means that the population would double in roughly twenty years from now, resulting in a population of about 350million people. The magnitude of the population growth will perhaps be of less significance 


\section{International Journal of Business Management and Economic Review}

Vol. 4, No. 06; 2021

ISSN: 2581-4664

than its direction and composition. The country's population growth rate will make it the third most populous nation on the planet in a mere two and a half decades. This huge population must be fed; therefore suppliers of food items are strategically positioned to create product supply chains that have exponential potential for growth (Otti, 2018). The government's current perspective of throwing more people into the sector is neither sustainable nor strategically sound; and indeed, it could be self-defeating. The more labour that is committed to fixed farm lands, the lower the marginal productivity per worker and the smaller the incomes per farm hands employed, thereby discouraging further labour supply.

Food in Nigeria has been consistently rising in price. This is because modern agricultural practice is still farfetched in Nigeria. According to Nelson (2019) Nigeria's inflation rate recorded a second consecutive increase at 11.40 per cent in May 2019, following a surge in food prices across the country. The composite food index rose by 13.79 per cent in May 2019, compared to 13.70 per cent in April 2019, led by increase in prices of meat, oils and fats, bread and cereals, potatoes, yam and other tubers, fish, milk, cheese and egg, and vegetables. The development, despite seasonal factors like farming period, was worsened by the recurring insecurity in the nation's food belts. The north central and north east states are agrarian centers that produce most of the staple foods consumed in the country. Prices have continued to soar, spiking inflation rates on a monthly basis. The NBS (2019), holds that the consumer price index increased by 0.03 per cent in May 2019, higher than the rate recorded in April 2019 (11.37 per cent). Month-on-month basis, the food subindex increased by 1.41 per cent in May 2019, up by 0.27 per cent from 1.14 per cent recorded in April 2019. The average annual rate of change of the food sub-index for the 12-month period ending May 2019 over the previous 12-month average was 13.37 per cent, against 13.34 per cent in April 2019 (NBS, 2019).

Food inflation in Nigeria has witnessed dramatic changes in recent years, reaching a peak of 20.32 percent in September 2017. Beginning from February 2016 food inflation as well as overall inflation has remained high at double digits (Egwuma, 2017). In a developing country like Nigeria, food price inflation is a critical economic problem posing threats to the poor who constitutes the large proportion of the population. According to the Central Bank of Nigeria, the average household in Nigerian spends about 73 percent of their income on food and beverage (Onyewuchi, 2016). Similarly, figures reported by USDA ( 2017) shows that Nigerians spend 58.9 percent of their household income on food. This figure, which represents the highest in the world, implies that Nigerians spend over half of their income on food. This situation is made worse in the light of recent economic deterioration which has placed Nigeria as the country with the largest number of extremely poor people, with about 87 million people living in extreme poverty and six people becoming extremely poor every minute (Kharas, 2018).

Some scholars have attributed the recent hike in price of food items to the recent border closure in Nigeria. For instance, according to Nkwor (2019), Nigerians recently have been lamenting as the prices of commodities skyrocket due to closure of the Nigerian borders. Food items such as rice, frozen foods and other commodities continue to increase up to $75 \%$. According to traders in major markets, the action is punitive because a lot of them who are doing legitimate businesses now have their containers stranded at the border. Nigerians are feeling the pangs of the border closure as the price of a bag of rice that was sold around $\$ 12,000$ to $\$ 15,000$ before now sells around $\$ 28$, 000. Also, a carton of frozen food (orobo chicken) that sold before at the rate of $\$ 8,000$ to $\$ 10,000$ 


\section{International Journal of Business Management and Economic Review}

Vol. 4, No. 06; 2021

ISSN: 2581-4664

now sells for $\$ 13,000$ to $\$ 15,000$ (Nkwo, 2019). Similarly John (2019) observed that Kaduna residents are now feeling the pains arising from the border closure as the prices of food stuff, such as rice, frozen foods and others continue to witness an increase of up to 50 per cent. A bag of rice that was sold around $\$ 12,000$ before now sells around $\$ 20,000$ to $\$ 22,000$. Besides, a carton of frozen food (orobo chicken) that was sold before at sthe rate of $\$ 7,000$ to $\$ 7,500$ now sells for $\$ 12,000$ to $\$ 13,000$.For every household in Kaduna city, these foods are essential to their survival because they are consumed in large quantity which necessitated their large importation. John (2019) further reported that a rice retailer, in Kakuri Market Kaduna, Alhaji Madugu Ibrahim lamented the absence of the locally produced rice which was the reason borders were shut, adding that they were not available. Hence, the Federal Government should have ensured self-sufficiency in rice before closing the borders. If the local rice is available, there won't be any increase in the price in the market (John, 2019).

From the fore going, the findings of this study validate the proposition that market focus of the APP hindered food accessibility in Nigeria. The findings show that the APP was basically keen at ensuring Nigeria's place in the export market rather than making domestic consumption a priority. Hence the resultant effect which is the poor availability of locally produced foods. Furthermore, the policy focused on value chain rather than production accounted for the increase in prices of food commodities.

\section{CONCLUSION}

The study assessed the implications of the market focus of the agricultural promotion policy on food security in Nigeria under the present administration. Evidence shown by this study indicates that a lot still has to be done in the agricultural sector in Nigeria. The financial commitment from government towards the agricultural sector is poor and inadequate making it difficult to achieve stipulated goals of agriculture in Nigeria. The structure of the Nigerian economy is highly disincentive to the agricultural sector given that huge priority is given to the oil sector because of the rent it accrues to the ruling elite. Even though the administration of President Mohammadu Buhari preaches diversification from oil to other sectors such as agriculture, there are still lapses in the implementation process. This is evident in the trend of national budgetary allocation to the sector. This has brought about shortfalls in the area of food production, processing and distribution in Nigeria. The farmers lack the wherewithal to produce enough food for domestic consumption. This has accounted for the rate at which food commodities are smuggled and imported into Nigeria. Therefore, if this shortfall is not checked, importation will always be a way out for Nigeria's teeming population to eat. The recent border closure will amount to nothing in Nigeria's economy if the local farmers still cannot access various agricultural technologies that will aid food production that will satisfy domestic consumption in Nigeria.

Two critical signs that demonstrate when a state is far from prioritizing a sector are: either the state is not listening or paying attention to the problem by way of evident political will to match all that the policy has presented or that the state is not channeling enough resources to that sector in order for the problem to be addressed in tandem with all that have been envisaged in the policy. Hence, the agricultural sector of Nigeria is yet to receive adequate prioritization from the government because the political will and enough resources are still channeled towards oil. However, until the 


\section{International Journal of Business Management and Economic Review}

Vol. 4, No. 06; 2021

ISSN: 2581-4664

aforementioned priority given to oil is given to agriculture, this policy and other subsequent agricultural policies are bound to fail. From the forgoing, the study recommends massive investment in the agricultural sector which will cover prioritization of rural infrastructure, incentivisation of agricultural technology, evolution of robust micro credit framework, adoption of targeted rural farmers financing policy and finally a demonstrable political will for diversification.

\section{REFERENCES}

Abdulrahaman, S. (2013). State of food security in Nigeria. International Journal of Social Science, 2(1) 1-6.

Ahungwa, G., Haruna, U., \& Abdusalam, Y. (2014). Trend analysis of the contribution of agriculture to the gross domestic product of Nigeria. Journal of Agriculture and Veterinary Science, 7(1), 50-55.

Akerele, D., Momoh, S., Aromolarm, A., Oguntona, C. \& Shittu, M. (2016). Food insecurity and coping strategies in south-west Nigeria. Springer Science+Business Media Dordrecht and International society for plant Pathology, 407-414.

Albert, C. \& Isife, B. (2009). Issues in developing a national policy on agricultural extension service in Nigeria: The perception of extension professionals. Agricultural Journal, 4(1), 22-26.

Beblawi, H. \& Luciani, G. (1987). The rentier state and the integration of the Arab world. London: Croom Helm.

Beblawi, H. (1990). Rentier state in the Arab world in G. Luciani (ed.), The Arab state (pp 66-90). London: Routledge.

Eze, C., Lemchi, J., Ugochukwu, A., Awulonu, C., \& Okon, A. (2010). Agricultural financing policies and rural development in Nigeria. A paper presented at the 84tth annual conference of the Agricultural Economics Society Edinburgh.

FAO (2015). The State of Food Insecurity in the World 2015. Meeting the 2015 International Hunger Targets: Taking Stocks of Uneven Progress, FAO in Conjunction with IFAD and WFP, Rome.

Federal Ministry of Agriculture and Rural Development (2016). The green alternative: Nigeria's Agriculture Promotion Policy 2016-2020 Document.

FGN (2019). National Security strategy. December, 2019.

Global Hunger Index (2019). International food policy research institute (GHI/IFPRI). Retrieved on June 20, 2019 from www.ifpri.org/publication/2019globalhungerindex

Iwuchukwu, C. \& Igbokwe, M. (2012). Lessons from agricultural policies and programmes in Nigeria. Journal of Law, Policy and Globalization, 5, 11-19.

Metu, A., Okeyika, O., \& Maduka, O. (2016). Achieving sustainable food security in Nigeria challenges and way forward in: $3^{\text {rd }}$ International Conference on African development issues (CU-ICADI), May 9-May 11, 2016, Covenant University, Ota, Nigeria.

National Bureau of Statistics (2011). National agricultural sample survey.

Odunze, I. (2018). A review of the Nigerian APP (2016-2020): Implications for entrepreneurship in the agribusiness sector. International Journal of Agricultural Policy and Research, 7(3), 70-79.

Ojong, F. \& Anam, B. (2018). Agriculture promotion policy 2016-2020 and rural development in 
International Journal of Business Management and Economic Review

Vol. 4, No. 06; 2021

ISSN: 2581-4664

Nigeria: Challenges and prospects. Journal of Humanities and Social Science, 23(2):24 29.

Soludo, C., (2004) Nigeria: National economic empowerment and development strategy. Abuja: National Planning Commission.

White, L. (1989). Political Analysis. Techniques and Practices. California: Book/Cole Publishing Company.

Yates, A. (1996). The rentier state in Africa, oil rent, dependency and neocolonialism in the republic of Gabon. Trenton, NJ: Africa World Press 